\title{
THE IMPLEMENTATION OF PEER FEEDBACK STRATEGY FOR WRITING INSTRUCTION AT THE FIRST SEMESTER OF WRITING 1 CLASS AT MUHAMMADIYAH UNIVERSITY OF METRO
}

By

\author{
Lilis Sholihah
}

Email:wardah_asyifa86@yahoo.com

\begin{abstract}
Peer feedback is one alternative strategy that can be used by the teacher/lecturer when conducting teaching writing. The procedure of the strategy enables the students to work cooperatively in a group/peer. The students can give comments on their classmates'writing for better quality writing. They also can learn how to revise their own text based on comments from peers. Peer feedback can be one solution to minimize the errors made by the students in their writing. The implementation of peer feedback in the classroom offers beneficial effects for the students either as the writers or as the readers. This method is appropriate design in improving the students writing ability.
\end{abstract}

\section{INTRODUCTION}

In the contex of education, it is worth remembering that most exams whether they are testing foreign language abilities or another skill, often rely on the students writing proficiency in order to measure their knowledge (Harmer, 2004:3). In line with this statement, writing which takes the last place of the focus is regarded as the most demanding skill (Nunan, 1991: 86, Mukminatien, 1997: 24, and Richards \& Renandya (2002: 303).

As the most demanding skills for language learner, writing has to be taught. In addition, writing is a learnt skill, it is usually learnt only when someone teaches us (Brown, 2007: 390). Moreover, the ability to write does not come naturally; it needs to be developed through lots of practices (Budiharso, 2005: 1). However, it is not easy to teach writing, the teacher has to explore various teaching techniques to help the students write better (Cahyono, 2001: 44).

One of the techniques that the resarcher would like to investigate in this research is peer feedback strategy. Peer feedback which is also called peer review is a learning strategy in which a student reviews another student's written work and provides feedback. Since students are asked to revise their work based on the feedback they receive, peer review puts the focus on the process of writing. Peer review is an active learning strategy 
with a number of benefits for learners. It focuses on the writing process, improves students' critical analysis skills, and allows them to improve their work before it is graded.Peer editing generally refers to commenting on a paper's organization, tone, format, flow, grammar, punctuation, and so on. Peer review usually includes an examination of the content as well (Rollinson, 2005:22).

Rollinson (2005:23) states that there are a number reasons why teacher/lecturer have to choose peer feedback in ESL writing classroom. Firstly, peer readers cn provide useful feedback. It has also been shown that peer writers can and do revise effectively on the basis of comment from peer readers. Another reason is that it tends to be of a different kind from that of the teacher. Caulk (1994) cited in Rollinson (2005:24) found that teacher feedback was rather general, whereas student responses were more specific. Finally, it may be that becoming a critical reader of other's writing may make students more critical readers and revisers of their own writing.

There are some reasons why the researcher chooses peer feedback to solve the student's writing problem. Firstly, it can be one solution to minimize the errors the students usually make in their writing before submit their writing draft to the teacher (Ur, 1996:172). It is supported by Hyland and Hyland (2006: 1) who suggest providing feedback and revisions during the process of writing can be more effective rather than at the end of the process. Secondly, peer responding can encourage students to participate in the writing conferences where they can obtain much information from each other to improve what they have written (O’Malley and Pierce, 1996:156; Brown, 2001:353).

\section{THEORETICAL BASIS}

\section{The Nature of Writing}

Hyland (2003:3) states that writing is a product constructed from the writer's command of grammatical and lexical knowledge, and the writing development is considered to be a result of imitating and manipulating models provided by the teacher. Writing is regarded as an extension of grammar, as a means of reinforcing language patterns through habit formation and testing learner's ability to produce well formed sentences.

Richards and Renandya (2002:303) state that writing is the most difficult skill for second language learners and the difficulty is not only in generating and organizing ideas, 
but also in transferring the ideas into texts. In line with the statement above, Hamp-Lyons (1990 cited in O'Malley\&Pierce, 1996:136) examines that writing is an act in which the writers take ideas and transfer them into "self-initiated" topics. To produce a piece of writing, a process of creating and recreating is needed until the writer is able to clarify and express the ideas in a clear way (Gebhard, 2000:222). Along with this, Brown (2007:391) states that written product is the result of thinking, drafting, and revising process that needs special skill and not everyone can develop it naturally.

Mukminatien (1997:1) and Alwasilah (2006:17) have noted that writing has been considered as the most neglected subject in Indonesian schools. It seems that many teachers ignore the importance of writing ability for the students' progress in English proficiency. Besides, there is an indication that one of the reasons why the teaching of writing seems to be neglected is due to assessment problems (Mukminatien, 1997:1).

According to Sundem (2006:41), the writing process comprises the mechanics by which writer creates publishable product. Writing process instruction is just that process oriented and encourages young writers to discover for themselves the mechanics of the composition. Of course the pieces of writing process differ depending on the type of writing being done. Teachers must encourage students to use the following strategies for example, prewriting, drafting, self revising, peer/adult revising, editing, and publishing.

This article describes the activities of process writing done by the students during which an action research study was carried out. The study aimed to facilitate students in the use of peer feedback strategy in order to improve their ability in writing paragraph.

\section{Peer Feedback Strategy}

According Stanley (1992) cited in Widiati (2004:205), peer response groups have long been widely accepted pedagogy in the first language (L1) English composition classroom. Research shows that peers can also make helpful contributes to students' writing development. They provide reader based feedback that show student writes the effect that the writing is having on a peer audience (Peterson, 2010:3).

Peterson (2010:2) says that peer feedback has the greatest impact such as: (1) the writer and her/his peers with ideas to move the writing forward when the writer is stuck; (2) Peers ask for clarification about something that is confusing or about missing information; (3) Peers give their emotional response to the writing (e.g. that it make them 
laugh or that they find a character repugnant; (4) Peers question the plausibility of particular events or ideas.

Based on the benefits of peer feedback when it is used in teaching writing, the researcher is interested to investigate peer feedbak in the teaching and learning process of writing. There are some reasons why the researcher chooses peer feedback to solve the student's writing problem. Firstly, it can be one solution to minimize the errors the students usually make in their writing before submit their writing draft to the teacher (Ur, 1996:172). It is supported by Hyland and Hyland (2006: 1) who suggest providing feedback and revisions during the process of writing can be more effective rather than at the end of the process. Secondly, peer responding can encourage students to participate in the writing conferences where they can obtain much information from each other to improve what they have written (O'Malley and Pierce, 1996:156; Brown, 2001:353). Along with this, Seow (2003:317) points out that peer responding can be effectively done in small groups or in pairs. It comes to mean that it can engage the students to actively offer feedback on each others' work. Moreover, it can be a possible way out when students react too passively to teacher feedback (Harmer, 2004:115). The last reason, when students are trained to evaluate their peer's work, they broaden their own opportunities to learn how to write (Cramer, 1982 cited in O'Malley\&Pierce, 1996:186).

Nevertheless, some problems might be appeared when implementing peer feedback strategy. There is a tendency that some students prefer to rely on the teachers' response (Hyland, 2003:198, Harmer, 2004:117, and Nelson \& Carson, 2006:43). As a result, they will ignore their peers' feedback. Besides, when providing feedback, students tend to focus on sentence level problem rather than ideas and organization (Hyland, 2003:198). This tendency might appear from the assumption that good writing is writing in which has rhetorical patterns (Widiati, 2004:211). Furthermore, teacher's assistances is needed to ensure that the students know how to give feedback and how to revise their own drafts based on their peers' feedback for the betterment of their writing quality (Widiati, 2004:222).

\section{The Implementation of Peer Feedback Strategy in Writing Instruction Research Setting and Subjects}

This study was conducted at University of Muhammadiyah Metro. The researcher chose writing 1 class that consist of 40 students. The students of writing 1 class were 
chosen as the subjects under some considerations. First, in the writing 1 class, the students are asked to have ability in writing the simple sentences, complex sentences and writing paragraphs. Here, the writer focused on writing paragraph. Second, the ability of students in writing paragraph was stiil poor. By using peer feedback technique, hopefully they can achieve at least the mastery of writing simple paragraph with specific topic about daily activity, traveling and future ambition, etc. Third, the ability of students writing should be built by the earlier level they learnt in University of Muhammadiyah Metro. Due to the fact that it become the bridge to have the ability in writing the complex one for example an essay.

\section{Practicing the Procedure of Peer feedback}

The procedures in applying peer feedback consisted some steps. In the initial meeting the students were assigned to do prewriting activity. They wrote down single words or phrases about a topic within 5 minutes. After that, the students developed and organized their ideas based on the topic. Then the students were ordered to write a minimum of 100 words for their first draft through elaborating their ideas. Finally, the students and the lecturer did reflection about what they had learned in the first meeting.

The next meeting was focused on the real activity of peer feedback. The students read one example of paragraph with some errors on grammar, spelling, preposition, and mechanics (punctuation, spelling, capitalization). The students were asked to discuss in groups and give feedback on paragraph by filling the revising checklist as the guidelines. There are some examples of the students first draft, as follows:

I have a nice memorian in Cirebon, ago. I was a best friends, his name is Pradhira Pratama Putra. He's smart student in our school, and he's that best in marching band group. He's very popular in our school, and he's very busy, but he's always stay in my side., for met me and hang out together, for a there years, but is not now. Formerly, the dream me and he is difficult, and we life is difficult too. After I graduated from MTsN babakan, I come back to lampung, and he was come back to bandung. Since the day, I never meet he again, but he's still my best friends. Until whenever, although I can't see him again.

Figure 1: the first example of first draft in writing paragraph from a student of the first semester in writing 1 course. 
I graduate from one of the popular senior high school in lampung. My school was a wide school with many buildings. It had 25 classes and three main offices. In front of the office there was a wide parking area for the student, teacher and staff. I felt so fantastic to study there. When I wanted to play basketball, I could go to the basketball yard in front of the canteen. My school also served some canteens in the middle part of my school. The menu was so delicious. I loved my school very much.

Figure 2: The second example of the first draft in writing paragraph from a student of the first semester in writing 1 course.

Moreoever, one of the examples checklist used by one student when the students implemented peer feedback as follows:

\begin{tabular}{|c|c|c|}
\hline Indikator & Deskripsi & Peer check \\
\hline Penggunaan huruf besar dan tanda baca. & $\begin{array}{l}\text { - Semua benar } \\
\text { - Hampir semua benar } \\
\text { - Sebagian benar } \\
\text { - Hampir semua salah } \\
\text { - Semua salah }\end{array}$ & $\checkmark$ \\
\hline Teknik penulisan paragraph & $\begin{array}{l}\text { - Semua benar } \\
\text { - Sebagian benar } \\
\text { - Semua salah }\end{array}$ & $\checkmark$ \\
\hline Penulisan ejaan & $\begin{array}{l}\text { - Semua benar } \\
\text { - Hampir semua benar } \\
\text { - Sebagian benar } \\
\text { - Hampir semua salah } \\
\text { - Semua salah }\end{array}$ & $\checkmark$ \\
\hline Kesesuaian kata kerja & $\begin{array}{l}\text { - Semua benar } \\
\text { - Hampir semua benar } \\
\text { - Sebagian benar } \\
\text { - Hamper semua salah } \\
\text { - Semua salah }\end{array}$ & $\checkmark$ \\
\hline
\end{tabular}




\begin{tabular}{|c|c|c|}
\hline Penggunaan Tenses & $\begin{array}{l}\text { - Semua benar } \\
\text { - Hampir semua benar } \\
\text { - Sebagian benar } \\
\text { - Hamper semua salah } \\
\text { - Semua salah }\end{array}$ & $\checkmark$ \\
\hline Penggunaan kata penghubung & $\begin{array}{l}\text { - Semua benar } \\
\text { - Hampir semua benar } \\
\text { - Sebagian benar } \\
\text { - Hamper semua salah } \\
\text { - Semua salah }\end{array}$ & $\checkmark$ \\
\hline Penggunaan Kosakata & $\begin{array}{l}\text { - Semua benar } \\
\text { - Hampir semua benar } \\
\text { - Sebagian benar } \\
\text { - Hamper semua salah } \\
\text { - Semua salah }\end{array}$ & $\checkmark$ \\
\hline Penggunaan kata ganti & $\begin{array}{l}\text { - Semua benar } \\
\text { - Hampir semua benar } \\
\text { - Sebagian benar } \\
\text { - Hampir semua salah } \\
\text { - Semua salah }\end{array}$ & $\checkmark$ \\
\hline \multicolumn{3}{|l|}{ Catatan: } \\
\hline
\end{tabular}

Table 1: Checklist of peer feedback

The last meeting consisted of discussing feedback and revising the students' first draft. The students got the feedback from their peers to revise their first draft and rewrite their draft as their final draft. Then, they submitted the final draft. Finally the reflection is done after they had learned the first, second and the third meeting.

I have pleasant memories in Cirebon. I have a best friend, his name is Pradhira Pratama Putra. He is a smart student in our school, and he is also the best in marching band group. He is very popular in our school. Eventhough he is busy, he alwasys stand in my side. We often meet 
and hang out together. We always together for about three years. But now we are separated. After I graduated from MTSN Babakan Ciledug, I come back to Lampung. Eventhough we never met again, I think he is still my best friend.

Figure 3: The example of final draft written by one student after doing peer feedback.

\section{CONCLUSION}

The implementation of peer feedback follows these procedures: (1) asking the students to compose their first draft, (2) discussing the meaning of items on revising checklist, (3) modeling how to provide feedback to the sample of paragraph writing, (4)ordering them to discuss and provide feedback to the sample of paragraph writing, (5) having them read and give feedback on their peers' drafts, (6) getting them to talk about each others' draft by giving comments and suggestion on their classmates' draft through elaborating on their checklists, (7) asking them to revise their draft based upon their peers' feedback, and (8) ordering them to rewrite their drafts as their final draft.

Furthermore, teacher's assistances is needed to ensure that the students know how to give feedback and how to revise their own drafts based on their peers' feedback for the betterment of their writing quality (Widiati, 2004:222).

\section{REFERENCES}

Alwasilah, A.C. 2006. From Local to Global: Reinventing Local Literature through English Writing Classess. TEFLIN Journal, 17 (1):11-25.

Brown, H.D. 2007. Teaching by Principles: An Interactive Approach to Language Pedagogy. San Francisco: Longman.

Budiharso, T. 2005. Basic Writing: The Rhetoric, Linguistics Features, and Material Development. Surakarta: Pustaka Cakra.

Cahyono, B. Y. 2001. Second Language Writing and Rhetoric: Research Studies in the Indonesian Context. Malang: State University of Malang Press.

Gebhard, G.J. 1996. Teaching English as a Foreign or Second Language: A Teacher SelfDevelopment and Methodology Guide. Ann Arbor: The University of Michigan Press.

Harmer, J.2004. How to Teach Writing. London: Longman.

Hyland, K.2003. Second Language Writing. Cambridge: Cambridge University Press. 
Hyland, K., \& Hyland, F. 2006. Contexts and Issues in Feedback on L2 Writing: An Introduction. In K. Hyland \& F. Hyland (Eds), Feedback in Second Language Writing (pp. 1-19). Cambridge: Cambridge University Press.

Mukminatien, N.1997. The Differences of Students' Writing Ability Achievement Across Different Course Level. Unpublished Dissertation. Malang: IKIP Malang.

Nunan, D. 1991. Language Teaching Methodology. New York: Prentice Hall.

O’Malley, J.M., \& Pierce, L.V. 1996. Authentic Assessment For English Language Learners. San Francisco: Longman.

Peterson, S. 2010. Improving Student Writing Using Feedback as a Teaching Tool. Journal of Research into Practice, 29 (2), 1-4

Richards, J.C. \& Renandya, W.A. 2002. Methodology in Language Teaching. Cambridge: Cambridge University Press.

Rollinson, P. 2005. Using Peer Feedback in the ESL Writing Class. ELT Journal, 59 (1), $23-30$

Seow, A. 2002. The Writing Process and Process Writing. In Richards, J.C. \& Renandya, W.A (Eds.), Methodology in Language Teaching (pp. 315-320). Cambridge: Cambridge University Press.

Sundem, G. 2006. Improving student writing skills. Huntington Beach: Shell Education.

Ur, P. 1996. A Course in Language Teaching: Practice and Theory. Cambridge: Cambridge University Press.

Widiati, U. 2003. Training EFL Writing Students in Indonesia in the Use of Strategies for Peer Response. Unpublished PhD Dissertation, Monash: Monash University.

Widiati, U. 2004. Training EFL Students in the Use of Peer Response. In B.Y. Cahyono \& U. Widiati (Eds.), The Tapestry of English Language Teaching and Learning in Indonesia (pp. 205-223). Malang: State University of Malang Press. 


\section{Appendix}

Berilah tanda (V) pada kolom yang tersedia untuk item yang anda periksa, kemudian tulislah temuan kesalahan dan saran perbaikan anda pada kolom peer notes yang tersedia.

\begin{tabular}{|c|c|c|}
\hline Indikator & Deskripsi & Peer check \\
\hline Penggunaan huruf besar dan tanda baca. & $\begin{array}{l}\text { - Semua benar } \\
\text { - Hampir semua benar } \\
\text { - Sebagian benar } \\
\text { - Hampir semua salah } \\
\text { - Semua salah }\end{array}$ & $\checkmark$ \\
\hline Teknik penulisan paragraph & $\begin{array}{l}\text { - Semua benar } \\
\text { - Sebagian benar } \\
\text { - Semua salah }\end{array}$ & $\checkmark$ \\
\hline Penulisan ejaan & $\begin{array}{l}\text { - Semua benar } \\
\text { - Hampir semua benar } \\
\text { - Sebagian benar } \\
\text { - Hampir semua salah } \\
\text { - Semua salah }\end{array}$ & $\checkmark$ \\
\hline Kesesuaian kata kerja & $\begin{array}{l}\text { - Semua benar } \\
\text { - Hampir semua benar } \\
\text { - Sebagian benar } \\
\text { - Hamper semua salah } \\
\text { - Semua salah }\end{array}$ & $\checkmark$ \\
\hline Penggunaan Tenses & $\begin{array}{l}\text { - Semua benar } \\
\text { - Hampir semua benar } \\
\text { - Sebagian benar } \\
\text { - Hamper semua salah } \\
\text { - Semua salah }\end{array}$ & $\checkmark$ \\
\hline Penggunaan kata penghubung & - Semua benar & $\checkmark$ \\
\hline
\end{tabular}


Premise Journal Vol 4 No I April 2015 ISSN: 2442-482x (cetak) ISSN: 977244248003 (electronic)

\begin{tabular}{|c|c|c|}
\hline & $\begin{array}{l}\text { - Hampir semua benar } \\
\text { - Sebagian benar } \\
\text { - Hamper semua salah } \\
\text { - Semua salah }\end{array}$ & \\
\hline Penggunaan Kosakata & $\begin{array}{l}\text { - Semua benar } \\
\text { - Hampir semua benar } \\
\text { - Sebagian benar } \\
\text { - Hamper semua salah } \\
\text { - Semua salah }\end{array}$ & $\checkmark$ \\
\hline Penggunaan kata ganti & $\begin{array}{l}\text { - Semua benar } \\
\text { - Hampir semua benar } \\
\text { - Sebagian benar } \\
\text { - Hampir semua salah } \\
\text { - Semua salah }\end{array}$ & $\checkmark$ \\
\hline \multicolumn{3}{|l|}{ Catatan: } \\
\hline
\end{tabular}

Adapted from Kusumawardani (2011:84) 